\title{
The Perception of Electorate in Kosovo on Structure of the Report between Political Ideology and Political Parties
}

\section{Burim Mexhuani*}

European University of Tirana, Albania

\begin{abstract}
This paper attempts to explain the perception of Kosovo's electorate about the relationship of political parties in Kosovo with ideology. For the purpose of empirical testing of the Ideology report with political parties in Kosovo as part of the study, it was judged to undertake a survey to investigate how the Kosovo electorate perceived the policy report with ideology. On primary resources, the data provided by the survey conducted with 310 respondents in Kosovo were used. Through this survey we will present the results of the interpretation of the data provided by the frequency tables and the cross tablets. In this presentation, generally, data from one-variable and two-variable crosstab data and statistical values of Cramer's V compilation values and Approx. Sig. to the Symmetric Measures table. After the data presentations, the interpretation of these values will be made with their possible significant statistical associations and the empirical test report on the implications under consideration.
\end{abstract}

Keywords: Kosovo; Respondent; Political parties; LDK; PDK; VV

\section{Introduction}

Earlier studies attempted to codify the ideological profiles of political parties in Kosovo, but it has been noted that their categorization into a category was impossible. Earlier studies profiled political parties as the head of the stated. This does not invalidate high dictation profiling because Political Parties in Kosovo parties are organizations to the hierarchy where decisions are taken by a small group of officials. Even countries with a long tradition in democracy find it difficult to categorize political parties into one or other ideology, not to talk a wartorn society that is still trying to combine its citizenship.

\section{Research question}

How is the relationship between ideology and political party structured in Kosovo structured? In response to this research question is given the basic assumption as follows.

\section{Basic assumption}

There is presently a judgment by the Kosovo electorate of an ideological grouping of the political programs and political activity of the Parties in the Republic of Kosovo.

In this research, we identified it as advantageous to develop early reviews by showing a study of the major political parties in Kosovo. Mutual promulgation of points of view is a further reasonable explanation of where a political party platforms and what tendency of polling can be supposed to have their members in the Parliament. This absence of ideological identity can simply be pointed out by the fact that the Political Parties in Kosovo were established during the democracy struggles. The parties were organized by groups that were assembled during the war or protection, and which integrated geography, occupation, or household commitments. Accordingly, we can express that the parties gather around themselves a corresponding contribution of radical, liberal or nationalist parties because these people were not at all a proof for their original approximation. Most of the parties were established before the state had a constitutional government and still before particular socio-industrial groups appearing to cooperate to fight for a strongly-established activity in election boxes or in the Parliament [1]. Evolutionary development towards the profiling of political parties was further delayed because
Kosovars did not rule the country mostly of the post-war period. For a long time, Kosovo was administered by the international community, which deprived the political elite of the country's government - and this non-participation in government spared local elected politicians from the need to position themselves on specific political issues. Since Kosovo is not a member of the UN, its foreign policy can allow itself not to take any stand on issues of international importance.

\section{Methodology}

For the purpose of factual analysis of the Ideology report with Political Parties in Kosovo as pulling out of the research, it was considered to offer a survey to study how the Kosovo electorate regarded the policy report with ideology. On essential sources, the factors presented by the survey showed with 310 respondents in Kosovo were needed. A survey serves to collect material that serves to empirically demonstrate an assumption explanation of use or underlying premise, there was a demand to explain such an explanation. In the process under review, the issue was confusion in formulating the program statement with ideology. Here are two questions that can be suggested:

How is the relationship between ideology and political parties organized in Kosovo? and, What is the organization of politics with ideology in Kosovo society?

Two results can be produced for these research questions, one for each. One in the set up of an assumption, which proves to point out the origins of such confusion. The second is the work of a key theory that precisely defines the system in question. Although uncertainty in the analysis may be limited and not fundamental, it was agreed to use in both areas: a) to point out this ambiguity; b) providing a coherent

*Corresponding author: Buriam Mexhuani, European University of Tirana, Albania, Tel: +355 4242 1806; E-mail: burimmexhuani@hotmail.com

Received September 22, 2017; Accepted September 27, 2017; Published October 04, 2017

Citation: Mexhuani B (2017) The Perception of Electorate in Kosovo on Structure of the Report between Political Ideology and Political Parties. Arts Social Sci J 8: 303. doi: 10.4172/2151-6200.1000303

Copyright: (c) 2017 Mexhuani B. This is an open-access article distributed under the terms of the Creative Commons Attribution License, which permits unrestricted use, distribution, and reproduction in any medium, provided the original author and source are credited. 
point of Kosovo's voter's consciousness of establishing the relationship between politics and ideology. Further, this research can be deeply analyzed by considering the changes in this report from the point of view of explaining its causes in the setup of an assumption. From this survey, besides the factors directed at empirical analysis of the main assumption, statistics have also collected that add to the analytical concept which considers the causes that produce ideology invisible to political parties in Kosovo. The survey presented not give appropriate questions about ideological tendencies but brought forward 12 (twelve) different queries on a variety of releases. Each answer corresponds to a positioning process, which thus enters in a diagram. To ensure that the survey can provide a good means for this task, We early analyze the main political ideologies around the world, as we will conduct a thorough analysis of the views expressed by the Political Parties in Kosovo. Due to the compound structure of the phenomenon, any new aspect, inaccessible to keep comprehensive study, but at least tried at handing over an analytical input to a small increase in the knowledge of the case and the circumstances that have shaped ambiguity in finding the scale of political parties to ideology in Kosovo. While empirical, provide test statistics collected from a survey based on the perception that Kosovo's electorate has on planning and releasing political parties in Kosovo with ideology. Since such a hypothesis is set up in the form of a judgment compelling or knowledge, an analysis is suggested if, then... So it goes on the one and only means to empirically implicitly prove it through empirical analysis of the Impacts inferred from it. So from this assumption reasonably have been developed Impacts of the tentative judgment, which gives the setting empirical test. Depending on the outcome of this analysis, it will be found whether or not the underlying assumption is common, which will conclude (but not reasonably!) The empirical analysis of the assumption in the query.

Under these conditions, the subsequent Impacts are deducted:

Indicator 1: If political party programs do not conform to the requirements that are accustomed by their ideological direction, thus the part of their ideologically-voted voter tends to vote less.

Indicator 2: If Political Parties choose on their elective programs steps that run respond to the traditional ideological wing politics they believe to belong to, they imperil losing support from their voter.

Indicator 3: If Political party programs do not match their activities in government, thus the pulling out of their ideologically-determined voter tends to vote less.

Of this rather general Impact, purer and better direct Impacts for the empirical analysis of the following can be deducted:

Indicator 3.1: If the PDK (Democratic Party of Kosovo) program appears not correspond with its actions in government then the pulling out of their ideologically-determined electorate tends to vote less.

Indicator 3.2: If the LDK (Democratic League of Kosovo) program appears not correspond with its actions in government then the pulling out of their ideologically-determined electorate tends to vote less

Indicator 3.3: If the VV (Self-Determination Movement) program appears not correspond with its actions in government then the pulling out of their ideologically-determined electorate tends to vote less

Impact of indicators 1: Indicators of right and left policy programs. Report of the programs of PDK, LDK and VV with these indicators. The voter's point of view concerning the consent of the programs with the indicators in question and the elective cost that predicts in case of discrepancy between them (Survey data of the result of the pulls that speak of ideological voting behavior).

Impact of indicators 2: Respondents' judgment referring to the perception of Political Parties voter of the distinctions between the program and the activities of the government [2].

Impact of indicators 2.1: Respondents' judgment referring to the perception of PDK voter of the distinctions between the program and the activities of the government [3].

Impact of indicators 2.2: Respondents' Opinions Concerning Perceptions by LDK Electorate of Differences between Program and LDK Actions in government [4].

Impact of indicators 2.3: Respondents' judgment referring to the perception of VV voter of the distinctions between the program and the activities of the government [5].

From this survey, in addition to data aimed at empirical analysis of the main hypothesis, are taken up factors that support the theoretical concept which consider the elements that cause the ideology invisible to political parties in Kosovo.

Based on the indicators, the question groups were set up to hand over the relevant material for the empirical analysis of each implication.

\section{Sample determination}

Since Kosovo becomes 1 (one) electoral area, the pattern is worked out by the indiscriminate sample method. More exactly, respondents from various municipalities of Kosovo have been singled out. In these conditions, a pattern survey was organized (based on age groups and gender), with the survey used included detailed queries referred to parties, their programs, the political wing of parties and respondents. The survey period lasted 10 days, on which occasion 310 respondents from 5 various age groups (18-25 years, 26-35 years old, 36-45 years old, 46-55 years and over 55 years) were interviewed; of whom $47 \%$ were women and 53\% males. After the finalization of the reception of the respondents, the data were retrieved and then placed in a database $[6,7]$. The data was put to the SPSS.20.0 program. After this, accurate statistical transform was completed, consisting of number tables, many charts and crossed tables designed to turn up the probable statistical associations of the worked out to empirically verify before assigned implications. You will meet them as attachments at the end of the work [8-11].

\section{Findings}

Through this survey we will hand out the results of reading the statistics presented by the number tables and the cross tablets. In this presentation data from one-variable and two-variable cross-tab data and statistical values of Cramer's V compilation values and Approx. Sig. to the Symmetric Measures table. After the data shows, understanding these values will be made with their potential symbolic statistical associations and the empirical test account for on the implications under discussion [12-15].

1. To find out the results of the surveys that speak of ideological or practical voting behaviour, we are making the table statistics that provides the answer to the query: "In general, will you say people have specific political views? We have the following results (Table 1).

From respondents' replies, we find out that people have specific political convictions at 85.5 percent versus $14.5 \%$ who oppose it. So the proportion of them is 5.9: 1 in support of assertions. Conforming 


\begin{tabular}{|c|c|c|c|c|c|}
\hline \multicolumn{6}{|c|}{ In general, will you say people have specific political views? } \\
\hline & & Frequency & Percent & Valid Percent & Cumulative Percent \\
\hline \multirow[t]{7}{*}{ Valid } & Yes, completely & 34 & 11.0 & 11.0 & 11.0 \\
\hline & Yes, to a great extent & 133 & 42.9 & 42.9 & 53.9 \\
\hline & Yes, somehow & 98 & 31.6 & 31.6 & 85.5 \\
\hline & More, no & 27 & 8.7 & 8.7 & 94.2 \\
\hline & Not at all & 11 & 3.5 & 3.5 & 97.7 \\
\hline & I do not know & 7 & 2.3 & 2.3 & 100.0 \\
\hline & Total & 310 & 100.0 & 100.0 & \\
\hline
\end{tabular}

Table 1: Political Convictions. (Survey data of the result of the pulls that speak of ideological voting behavior, 2017).

\begin{tabular}{|c|c|c|c|c|c|}
\hline \multicolumn{6}{|c|}{ With the query "Do you know the political party programs in our country?" } \\
\hline & & Frequency & Percent & Valid Percent & Cumulative Percent \\
\hline \multirow[t]{7}{*}{ Valid } & Yes, for all parties & 23 & 7.4 & 7.4 & 7.4 \\
\hline & Yes, for most of them & 53 & 17.1 & 17.1 & 24.5 \\
\hline & Yes, for some of them & 128 & 41.3 & 41.3 & 65.8 \\
\hline & Yes, just for a party & 6 & 1.9 & 1.9 & 67.7 \\
\hline & No, for no party & 90 & 29.0 & 29.0 & 96.8 \\
\hline & I do not know & 10 & 3.2 & 3.2 & 100.0 \\
\hline & Total & 310 & 100.0 & 100.0 & \\
\hline
\end{tabular}

Table 2: The political party programs in Kosovo. (Survey data of knowing the political programs, 2017).

\begin{tabular}{|c|c|c|c|c|c|}
\hline \multicolumn{6}{|c|}{ Do you think people, in general, know how to distinguish whether a party's program belongs to the political wing it claims to belong to? } \\
\hline & & Frequency & Percent & Valid Percent & Cumulative Percent \\
\hline \multirow[t]{7}{*}{ Valid } & Yes, completely & 18 & 5.8 & 5.8 & 5.8 \\
\hline & Yes, to a great extent & 40 & 12.9 & 12.9 & 18.7 \\
\hline & Yes, somehow & 114 & 36.8 & 36.8 & 55.5 \\
\hline & More, no & 108 & 34.8 & 34.8 & 90.3 \\
\hline & Not at all & 20 & 6.5 & 6.5 & 96.8 \\
\hline & I do not know & 10 & 3.2 & 3.2 & 100.0 \\
\hline & Total & 310 & 100.0 & 100.0 & \\
\hline
\end{tabular}

Table 3: Political wings. (Survey data of knowing the ideology of a political party, 2017).

to this it can be estimated that the Kosovo voter can be assumed in its larger part as a political one [16-20].

2 . With the query "Do you know the political party programs in our country?", We have the following data (Table 2).

From these shreds of evidence, it can be identified that approximately $68 \%$ of respondents declare that they have seen the programs of at least one political party (from one party to all parties) versus roughly $33 \%$ who claim they know none political party program. So the proportion of them is 2.1:1 for the favour of the recognition of political party programs $[21,22]$.

3. When asked "Do you think people, in general, know how to distinguish whether a party's program belongs to the political wing it claims to belong to?", We have the following information (Table 3).

From this evidence, it can be understood that $55.5 \%$ of people, in general, can understand whether a political party program belongs to the wing it claims to belong to versus $44.5 \%$ who oppose it. So the scale between them is 1.1: 1 value clearly in approve of recognizing the argument [23-25].

4. To the question that. "Do you think that the general public does not judge that their party should be punished simply because its program does not fully or to a large extent conform to the ideological orientation it claims to belong to?" these data (Table 4).

From this evidence, $73.6 \%$ declare to our query, related to $26.4 \%$ who express negative deal with to this query. So the ratio between them is $2.7: 1$ to support positive feedbacks. From this data, one can make the analysis we have an acceptance of an act of pragmatic voters at the stage of respondents. This report is a negative result of empirical testing of Indicator $1[26,27]$.

5. The question: "As long as you know, people generally consider PDK a party that belongs to an ideological wing?” We have these data (Table 5).

From these data, people consider PDK as a left-wing party with $28.1 \%$ versus $14.2 \%$ as important as a right-wing party (ratio $1.98: 1$ ) and $14.2 \%$ who do not list PDK in no wing. However, about $8 \%$ of respondents do not figure out the ideological direction of this party. So from these data, it can be said adequately is a need of clarity about the ideological identity of this party.

6. The question: "As far as you know, in general, people consider LDK as a party belonging to an ideological wing" we have the following data (Table 6).

9.7\% who consider it as a left-wing party versus $59.7 \%$ (ratio 1 : 6.15) claim LDK is positioned as a right-wing party and $8.4 \%$ do not class it on either side. So, about $15 \%$ do not recognize the LDK as a right-wing party. This proves that there is confusion in the ideological status of this party.

7. The question: "As far as you know, in general, people consider $\mathrm{VV}$ as a party belonging to an ideological wing", we have the following data (Table 7) $66.9 \%$ of respondents identify the VV as a left-wing party versus 7\% (proportion 9.5: 1) consider them as a right-wing party, and $13.4 \%$ declare that it does not belong to any ideological wing. So, around 
Citation: Mexhuani B (2017) The Perception of Electorate in Kosovo on Structure of the Report between Political Ideology and Political Parties. Arts Social Sci J 8: 303. doi: 10.4172/2151-6200.1000303

Page 4 of 7

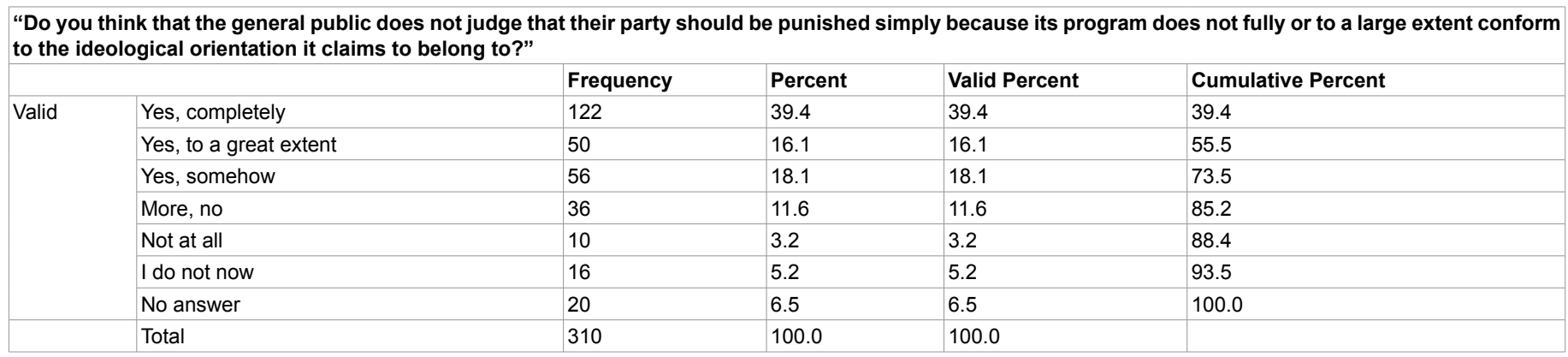

Table 4: The behavior of pragmatic voters (Survey data of knowing the ideological orientation of political parties, 2017).

\begin{tabular}{|c|c|c|c|c|c|}
\hline \multicolumn{6}{|c|}{ As long as you know, people generally consider PDK a party that belongs to an ideological wing? } \\
\hline & & Frequency & Percent & Valid Percent & Cumulative Percent \\
\hline \multirow[t]{13}{*}{ Valid } & In the far left & 21 & 6.8 & 6.8 & 6.8 \\
\hline & In the left wing & 49 & 15.8 & 15.8 & 22.6 \\
\hline & In the center of the left & 17 & 5.5 & 5.5 & 28.1 \\
\hline & In the center right & 10 & 3.2 & 3.2 & 31.3 \\
\hline & On the right wing & 20 & 6.5 & 6.5 & 37.7 \\
\hline & In the far right & 14 & 4.5 & 4.5 & 42.3 \\
\hline & In no wing & 29 & 9.4 & 9.4 & 51.6 \\
\hline & Other & 8 & 2.6 & 2.6 & 54.2 \\
\hline & I do not know & 90 & 29.0 & 29.0 & 83.2 \\
\hline & No answer & 12 & 3.9 & 3.9 & 87.1 \\
\hline & Next: nowhere & 15 & 4.8 & 4.8 & 91.9 \\
\hline & Next: I do not clearly see & 25 & 8.1 & 8.1 & 100.0 \\
\hline & Total & 310 & 100.0 & 100.0 & \\
\hline
\end{tabular}

Table 5: PDK party (Survey data of knowing the political program of PDK, 2017).

\begin{tabular}{|c|c|c|c|c|c|}
\hline \multicolumn{6}{|c|}{ As far as you know, in general, people consider LDK as a party belonging to an ideological wing } \\
\hline & & Frequency & Percent & Valid Percent & Cumulative Percent \\
\hline \multirow[t]{12}{*}{ Valid } & In the far left & 6 & 1.9 & 1.9 & 1.9 \\
\hline & In the left wing & 4 & 1.3 & 1.3 & 3.2 \\
\hline & In the center of the left & 20 & 6.5 & 6.5 & 9.7 \\
\hline & In the center right & 106 & 34.2 & 34.2 & 43.9 \\
\hline & On the right wing & 66 & 21.3 & 21.3 & 65.2 \\
\hline & In the far right & 13 & 4.2 & 4.2 & 69.4 \\
\hline & In no wing & 21 & 6.8 & 6.8 & 76.1 \\
\hline & Other & 2 & .6 & .6 & 76.8 \\
\hline & I do not know & 57 & 18.4 & 18.4 & 95.2 \\
\hline & No answer & 5 & 1.6 & 1.6 & 96.8 \\
\hline & Next: nowhere & 10 & 3.2 & 3.2 & 100.0 \\
\hline & Total & 310 & 100.0 & 100.0 & \\
\hline
\end{tabular}

Table 6: LDK party (Survey data of knowing the political program of LDK 2017).

$20.4 \%$ do not perceive the VV as a left-wing party. This indicates that although there is a great percentage of them looked at as the Left Party, there is still confusion in the ideological status of this party.

8. The question: "Do you consider PDK's activities in power differ the programs declared during election campaigns? (Table 8).

$87.7 \%$ of respondents expect there are discrepancy s between the PDK's activities and the ideological orientation it claims to belong to $12.3 \%$ of those who oppose it. The proportion between them is 7.1:1 in support of affirmation (Table 9).

9. Do you consider LDK's activities in power differ the programs declared during the election campaigns?? (Table 10). $71.0 \%$ of respondents consider there is a discrepancy between LDK actions in governance with programs declared during ballot campaigns, compared to $29.0 \%$ of those who oppose it. The proportion between them is 7.1:1 to support affirmation. The question: "Do you consider LDK's activities in power differ the programs declared during the ballot campaigns? If YES, in such situations, do you consider in case of discrepancy between the LDK's activities in the governing and ideological orientation it claims to belong to, the voter will react by not voting for this party (Table 11 ). $56.8 \%$ of respondents think that the actions of the ruling LDK do not match the programs announced during the election campaigns, think that the electorate will react with no vote to this party in the next election. Meanwhile, $37.8 \%$ who claim that there are discrepancies between the government's actions and the program stated in the electoral campaign and think that the electorate will react by not voting for this in the next election. So the ratio between them is $1.5: 1$ for the benefit of the non-voting option. This report shows a positive result of the empirical testing of the Indicator 3.2 The 
Citation: Mexhuani B (2017) The Perception of Electorate in Kosovo on Structure of the Report between Political Ideology and Political Parties. Arts Social Sci J 8: 303. doi: 10.4172/2151-6200.1000303

Page 5 of 7

\begin{tabular}{|c|c|c|c|c|c|}
\hline \multicolumn{6}{|c|}{ As far as you know, in general, people consider LDK as a party belonging to an ideological wing } \\
\hline & & Frequency & Percent & Valid Percent & Cumulative Percent \\
\hline \multirow[t]{12}{*}{ Valid } & In the far left & 78 & 25.2 & 25.2 & 25.2 \\
\hline & In the left wing & 42 & 27.5 & 27.5 & 38.7 \\
\hline & In the center of the left & 13 & 14.2 & 14.2 & 42.9 \\
\hline & In the center right & 6 & 1.9 & 1.9 & 44.8 \\
\hline & On the right wing & 5 & 1.6 & 1.6 & 46.5 \\
\hline & In the far right & 11 & 3.5 & 3.5 & 50.0 \\
\hline & In no wing & 25 & 8.1 & 8.1 & 58.1 \\
\hline & Other & 5 & 1.6 & 1.6 & 59.7 \\
\hline & I do not know & 113 & 6.5 & 6.5 & 96.1 \\
\hline & No answer & 1 & 5.3 & 5.3 & 96.5 \\
\hline & Next: nowhere & 11 & 4.1 & 4.1 & 100.0 \\
\hline & Total & 310 & 100.0 & 100.0 & \\
\hline
\end{tabular}

Table 7: VV party (Survey data of knowing the political programs of VV, 2017).

Do you consider PDK's activities in power differ the programs declared during election campaigns

\begin{tabular}{|l|l|l|l|l|l|}
\hline \multirow{2}{*}{ Valid } & Yes & Frequency & Percent & Valid Percent & Cumulative Percent \\
\cline { 2 - 7 } & No & 272 & 87.7 & 87.7 & 100.0 \\
\hline & Total & 38 & 12.3 & 12.3 & 100.0 \\
\hline
\end{tabular}

Table 8: PDK's activities in the government (Survey data of knowing the PDK's political program, 2017).

Do you consider PDK's activities in power differ the programs announced during election campaigns? If YES, in such instances, do you consider in case of discrepancy between PDK's activities in governing and ideological direction it takes to belong to, the voter will proceed by not voting for this party.

\begin{tabular}{|c|c|c|c|c|c|}
\hline & & Frequency & Percent & Valid Percent & Cumulative Percent \\
\hline \multirow[t]{10}{*}{ Valid } & Yes, completely & 13 & 4.2 & 4.8 & 20.7 \\
\hline & Yes, to a great extent & 19 & 6.2 & 7.0 & 76.8 \\
\hline & Yes, somehow & 54 & 17.4 & 35.3 & 91.0 \\
\hline & More, no & 96 & 31.0 & 20.6 & 95.2 \\
\hline & Not at all & 56 & 18.0 & 19.8 & 96.1 \\
\hline & I do not know & 20 & 6.5 & 7.4 & 98.7 \\
\hline & No answer & 14 & 4.5 & 5.1 & 100.0 \\
\hline & Total & 272 & 87.7 & 100.0 & \\
\hline & Missing system & 38 & 12.3 & & \\
\hline & Total & 310 & 100.0 & 100.0 & \\
\hline
\end{tabular}

Table 9: PDK's activities during election (Survey data of knowing the PDK's action in the government contradict the program declared during election campaigns, 2017).

Do you consider LDK's activities in power differ the programs declared during the election campaigns?

\begin{tabular}{|c|c|c|c|c|c|}
\hline & & Frequency & Percent & Valid Percent & Cumulative Percent \\
\hline \multirow[t]{3}{*}{ Valid } & Yes & 220 & 71.0 & 71.0 & 71.0 \\
\hline & No & 90 & 29.0 & 29.0 & 100.00 \\
\hline & Total & 310 & 100.0 & 100.0 & \\
\hline
\end{tabular}

Table 10: LDK's activities during the election campaigns (Survey data of knowing the LDK's political program, 2017).

Do you consider LDK's activities in power differ the programs declared during the ballot campaigns? If YES, in such situations, do you consider in case of discrepancy between the LDK's activities in the governing and ideological orientation it claims to belong to, the voter will react by not voting for this party

\begin{tabular}{|c|c|c|c|c|c|}
\hline & & Frequency & Percent & Valid Percent & Cumulative Percent \\
\hline \multirow[t]{10}{*}{ Valid } & Yes, completely & 23 & 7.4 & 10.4 & 95,2 \\
\hline & Yes, to a great extent & 58 & 18.7 & 26.4 & 76,8 \\
\hline & Yes, somehow & 44 & 14.2 & 20.0 & 91,0 \\
\hline & More, no & 80 & 25.8 & 36.4 & 20,7 \\
\hline & Not at all & 3 & 1.0 & 1.4 & 96,1 \\
\hline & I do not know & 8 & 2.6 & 3.6 & 98,7 \\
\hline & No answer & 4 & 1.3 & 1.8 & 100,0 \\
\hline & Total & 220 & 71 & 100.0 & \\
\hline & Missing system & 90 & 29.0 & & \\
\hline & Total & 310 & 100.0 & 100.0 & \\
\hline
\end{tabular}

Table 11: LDK's activities in the governing and ideological orientation (Survey data of knowing the LDK's action in the government contradict the program declared during election campaigns, 2017) 


\begin{tabular}{|c|c|c|c|c|c|}
\hline \multicolumn{6}{|c|}{$\begin{array}{l}\text { In your opinion do you generally think that there is a disc } \\
\text { cases, do you think that in case of discrepancy between } \\
\text { no vote to that party }\end{array}$} \\
\hline 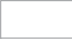 & 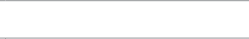 & Frequency & Percent & Valid Percent & Cumulative Percent \\
\hline \multirow[t]{9}{*}{ Valid } & Yes, completely & 49 & 15.8 & 31.4 & 31,4 \\
\hline & Yes, to a great extent & 22 & 7.1 & 14.1 & 45,5 \\
\hline & Yes, somehow & 29 & 9.4 & 18.6 & 64,1 \\
\hline & More, no & 34 & 11.0 & 21.8 & 85,9 \\
\hline & Not at all & 11 & 3.5 & 7.1 & 92,9 \\
\hline & I do not know & 11 & 3.5 & 7.1 & 100,0 \\
\hline & Total & 156 & 50.3 & 100.0 & \\
\hline & Missing system & 154 & 49.7 & & \\
\hline & Total & 310 & 100.0 & 100.0 & \\
\hline
\end{tabular}

Table 12: VV's activities and ideological orientation (Survey data of knowing the VV's program and ideological wing, 2017).

question: Do you think there is a discrepancy between VV's program and the ideological wing it claims to belong to? If YES, in such cases, do you think in case of discrepancy between the VV program and the ideological wing that does not claim it belongs, the electorate will react with no vote to that party? We have these data (Table 12). From the table we understand that $64.1 \%$ of the respondents who claim to have discrepancies between the VV program and the ideological wing that it claims to belong to the electorate will react by not voting for this party in the next election. While $7.1 \%$ of respondents claiming there are discrepancies between the VV program and the ideological wing that it claims to belong to, do not think the electorate will react by not voting this party in the next election. The ratio between them is 9.0:1 against the non-voting option. So even in this case we have a negative result of empirical testing.

\section{Analysis of Results}

Considering the above results we have examined in specific the results of the empirical analysis of those means related to the empirical test of the basic hypothesis. On Indicator 1 we have empirical test results emerging from the crossing tables of the triads of variables linked to PDK and LDK. From the trio crosses related to PDK emerges that we have 2 negative tests. But from the crossed-down triangles that are related to LDK it turns out that we have 2 positive tests. By analyzing the statistic tables on the returns to the question "Can people consider that a party should be penalized simply because its program not or to a considerable extent conform to the ideological wing what does it pretend to belong?" We have a negative result of empirical testing of Indicator 1. Respondents support the implication 1 for the PDK and LDK electorate, and reject it for the electorate of VV. But we also have a negative result of the empirical testing of the implication, so the proportion between them is $2: 1$ in favour of the negative result of the empirical test of the Indicator 1 . As far as the VV party from the table is regarded, $64.1 \%$ of the respondents claiming there are differences between the VV's program and the ideological wing it claims to belong, the voter will react to not vote for this party in the next election. While $7.1 \%$ of respondents claiming there are discrepancies between the VV program and the ideological wing it claims to belong to, do not think the electorate will react by not voting this party in the next election. The ratio between them is 9.0: 1 against the non-voting option. So even in this case we have a negative result of empirical test.

\section{Conclusions}

The limitation of this paper is that it consists of particularly the three main political parties in Kosovo. These results in outcomes cannot be so representative in other cases that they cannot be generalized. In this paper, we concentrated mainly on the vagueness of structuring political party reports with political ideology. The study is dealt with in two stages: the initial is that the uncertainty of structuring political parties with ideology is noticed in their electoral programs and the second is political discourse. We can conclude that there is confusion in setting up the political party's report with ideologies. Generally, political parties determine programs that are not in line with the ideological political matrixes they declare they belong to. The same ambiguity situation is further indicated in the relationship between political activity and the demands that derive from the political wing they claim to belong. Comparing the report of ideology with political parties in the Republic of Kosovo, we note that the uncertainties in structuring the report in question are conditioned by social, economic and political factors such as: Kosovo status settlement [6], dynamics of structuring groups the role of internationals in Kosovo, the inadequate role of NGOs in organizing and mobilizing citizens to protect the partial interests of some social groups, the lack of ideological structured elites and the globalization effects. This paper is an aid to the definition of this report between Political Parties in Kosovo and Ideology and the building of a democratic society in Kosovo. In supplement to its academic value, this identification and categorization is intended to assist political parties in assessing the degree of coherence for the entire public policy issues among senior leaders [28,29]. Most parties have not even moved from normative statements, which show the desire of leadership in what direction it intends to develop the party. The profile they ask for does not coincide with the position they have on different issues, nor with the history of their voting in the Assembly. Worse still, the party's senior leadership is not a map of political party orientation to turn the ideological denomination into concrete guidance on how to vote and position lower-level officials and sympathizers. Whether the party will reach the destination designated by its governing bodies depends on the opinions of a wider group of leaders. For this, it was essential to analyze the main political party in Kosovo such as Democratic Party of Kosovo - DCP and Democratic League of Kosovo - LDK, which has held the main burden of building the state of Kosovo. This paper also analyzes the political discourses of a wider circle of influential party officials and activists [30-32]. The consistency of political parties' positions is of fundamental importance in the transition, as the parties transform themselves from being the means to realize the interests of certain groups in being a representative of a stable base of voters with specific common interests.

\section{References}

1. Muir R (1997) Political geography: A new introduction, UK: Macmillan Education UK.

2. Survey- The electorate's opinion (2017) 
Citation: Mexhuani B (2017) The Perception of Electorate in Kosovo on Structure of the Report between Political Ideology and Political Parties. Arts Social Sci J 8: 303. doi: 10.4172/2151-6200.1000303

Page 7 of 7

3. Survey data of knowing the PDK's political program (2017).

4. Survey data of knowing the political program of LDK (2017).

5. Survey data of knowing the political programs of VV (2017).

6. Ch Kosovo (2008) World Politics: Trend and Transformation. Cengage Learning.

7. Arend Lijphart (1999) Patterns of Democracy. Government Forms and Performance in Thirty-Six Countries. New Haven and London: Yale University Press.

8. Aristoteli (2002) Politika Tirane, CEU.

9. Beck U (2000) What is Globalization? Oxford: Polity Press.

10. Castels M (2010) The Power of Identity, London and New York: Wiley Blackwell.

11. Civici A (2009) Globalizimi. Tirana: UET press.

12. Cox WR (1992) Multilaterismm and Democracy.

13. Eulex-kosovo.eu (2012).

14. Heywood A (2007) Political ideologies, An introduction. Palgrave: Macmillan.

15. Hobssbawn E (1994) Epoka e Ekstremeve. Tirana: Cabej.

16. Kegey C (2008) World Politics: Trend and Transformation, Cengage Learning.

17. Carroue L, Collet D, Ruiz C (2005) La Mondalization, Genese, acteurs et enjeux. Breal.

18. LDK election program (2017).

19. Mackie G (2003) Schumpeter's Leadership Democracy. San Diego: University of California.
20. Maloku F (2004) Developing countries have the IMF single developmental address, while Kosovo itself.

21. Ostrogorski ML (2009) Democracy and the Organization of Political Parties The United States, New York:Transaction Publishers.

\section{PDK program}

23. Pelevik J (2003) Pas Globalizimit, Prishtine: Kolegji Universitar Victory. Pristina: Kolegji Universitar Victory.

24. Platoni (2002) Republika. Tiranë: CEU.

25. Plevnik J (2003) Pas globalizimit, Tiranë: Golden Marketing,. Tirana: Golden Marketing

26. Sartori G (1993) Edhe një herë për teorinë e demokracisë. Tiranë: Dituria.

27. Smith Baylis and Owens (2010) The Globalization of World Politics.

28. Thomas JA (2005) The Handbook of Political Sociology: States, civil societies and globalization. Cambridge University Press.

29. Thomas J, Alfird R Hicks, A.Schwatz, M (2005) The Handbook of Political Sociology: States, civil societies and globalization. Cambridge University Press.

30. Walzer MM (1992) The Civil Society Argument in C. Mouffe, Dimensions of Radical. New York: Verso.

31. Zaleski PS (2008) Tocqueville on Civilian Society. A Romantic Vision of the Dichotomic Structure of Social Reality.

32. Almond G, Verba S (1989) The Civic Culture: Political Attitudes and Democracy In Five Nations, Sage. 